and the component parts are completely biodegradable. It is so durable it can last hundreds of years without upgrades. Best of all, this Technology is incredibly accessible....

To which one tired student with chin on hand replies: "You're talking about a book." The teacher responds, "Pretty cool, huh?" "Yeah." "Sure." Because Shockey does not give us a reading of the comic directly, he leaves us to make our own meanings from the cartoon. Here is mine: Shockey is like the curmudgeonly old teacher; and we (his readers) are in the position of the bored students, yawning at our teacher's fascination with the story he tells of the once new, now old medium and its uncanny similarities to today. Shockey never says that the human right of access to our digital cultures today is the same as the problem of bourgeois access that his book recounts about the laborers of the print factory who could not afford the commodities which they helped produce in mass quantities. Today, such laborers are the functional equivalent of those who work in our e-commerce "fulfillment centers," who can't afford high speed internet for their children to be home schooled during the pandemic, and who have no hope of having their own consumerist dreams being fulfilled. And if that comparison is apt (and I think it is), then the entire argument of Typographic Imagination falls on its (type)face. Rather than a historically nuanced argument about how type changed everything; we are left with a universal-media shifts change nothing. Power hierarchies organized by capital around media from Heian through today (despite the advents of the typographic and the digital) continue to wreak havoc on the underclasses.

\title{
Unbinding The Pillow Book: The Many Lives of a Japanese Classic
}

By Gergana Ivanova, New York: Columbia University Press, 2018. xi, 226 pp. \$75.00.

\section{Reviewed by}

Anne Commons

This is a very welcome addition to the rather limited amount of Englishlanguage scholarship on The Pillow Book (Makura no sōshi, early eleventh century), that famously unclassifiable compendium of essays, lists, and 
memoirs written by Sei Shōnagon (964?-after 1027), lady-in-waiting to Teishi (976-1000), consort to Emperor Ichijō (980-1011, r. 986-1011). Ivanova's main focus here is not the Makura no sōshi itself, but its afterlife in the early modern period (Edo, 1603-1867; Meiji, 1868-1912), when, like many other Heian-period (794-1185) literary classics, it was taken up and adapted for the vast new non-elite readership emerging in Edo and other cities.

The first chapter is entitled "What is The Pillow Book?," and Ivanova shows us the difficulty of answering that question through her description of the multifaceted nature of the text. The varied and heterogeneous character of the Makura no sōshi in terms of both form (lists, reminiscences, essays) and content (highly intertextual, drawing on both Japanese and Chinese sources) is what both gives the text its richness and interest and has led to its canonical marginalization, unable to fit neatly into a convenient literary category. As a product of a Heian court salon, the Makura no sōshi has historically been unfavorably compared with the Genji monogatari (Tale of Genji, early eleventh century); when (anachronistically) classified as a zuihitsu (or miscellany), it has historically been unfavorably compared with Tsurezuregusa (Essays in idleness, ca. 1330-1331). Ivanova signals her intention to rectify matters, and to introduce new ways of considering literary reception, through an explanation of her title, in which "unbinding" refers both to the selective reading of parts of the Makura no sōshi (as if the book has been "unbound" and select pages removed and taken as representative of the whole, a common feature of the work's reception), and to the idea of releasing (or "unbinding") both the Makura no sōshi and its author from the categories into which they have been forced. Building on the work of scholars such as Joshua Mostow and Michael Emmerich, she sets out to demonstrate that the reception of the Makura no sōshi can only be understood if one embraces the multifaceted and non-unitary nature of both the original work and the ways in which it came to be adopted, adapted, reread, and rewritten by and for later audiences. The timeliness of Ivanova's work is also made clear when she points out that the scholarly field of Makura no sōshi reception studies has really only developed in the last two decades, hampered by precisely the kind of blinkered reception of the text that she is arguing against in her study.

The difficulty of tracing the reception history of the Makura no sōshi before the early modern period lies in its multiple textual lines, no one of which was dominant, and the lack of any pre-Edo commentaries on the 
text. In the Edo period, however, the Makura no sōshi was collated and annotated for the first time as a step towards the construction of a "definitive" version (or versions) of the text for publication. In her second chapter, "(Re)constructing the Text and Early Modern Scholarship," Ivanova examines this process, showing that this Edo-period reconstruction of the text "was not the writing of Sei Shōnagon but a product of extensive manipulations at the hands of male scholars in the centuries following the completion of the work" (19). The three "complete" annotated versions of the Makura no sōshi to emerge in the Edo period were all created by male haikai poets, all of whom stressed the work's associations with classical waka in an attempt to foreground its aristocratic nature. As Ivanova shows, what is striking about these three commentaries is that they all present quite different versions of the primary text, each consisting of passages drawn from various textual lines and arranged according to the author's purpose (or, as Ivanova diplomatically states, "following a logic that remains obscure to later readers") (28). It is from this process of textual (re)construction that the first "standard" version of the text emerged, that compiled by Kitamura Kigin (1624-1705) in 1674. Another significant point in the reception of the Makura no sōshi came a century later, in 1774, when the scholar and poet Ban Kōkei (1733-1806) was the first writer to describe the text as a zuihitsu. Kōkei did not define the term zuihitsu, and seems to have included the Makura no sōshi within this category for ideological reasons, mainly as proof of the antiquity of essay-writing in Japan. Ivanova shows how Kōkei's fateful application of the term zuihitsu to the Makura no sōshi has unfavorably influenced the reception of both the text and its author up to the present day. However, this is only one aspect of the Edo-period reception of the Makura no sosshi: as is so often the case, while scholarly reception of the text went in one direction, popular reception went in quite another.

In chapter 3, "From a Guide to Court Life to a Guide to the Pleasure Quarters," Ivanova begins her examination of the Makura no sōshi's popular reception. The feature of the Makura no sōshi which was most seized upon by early modern cultural producers and consumers was the lists which make up about one-third of the text. Sei Shōnagon's lists of various Heian phenomena dovetailed neatly with the noted early modern enthusiasm for cataloguing and classifying information, and list-based adaptations of the Makura no sōshi in fact preceded the aforementioned commentaries into print. The main focus of the third chapter is parodies or adaptations of the Makura no sōshi written by and for men, from a male 
perspective. These include the earliest Makura no sōshi parody, the Inu makura (Dog pillow, 1600), with its implicit emphasis on wakashu (adolescents) within the context of male-male relationships, and books associated with the licensed pleasure quarters. Ivanova shows how the culture and etiquette of the pleasure quarters were imaginatively modelled on the elegant courtship practices depicted in Heian-period texts such as the Makura no sōshi or Genji monogatari; in such a context, Sei Shōnagon and her contemporaries came to be regarded as the forerunners of contemporary courtesans. While drawing on classic texts allowed the writers of the pleasure quarters to lay claim to the cultural capital they embodied, this mode of adaptation reduced Sei Shōnagon and other Heian writers from accomplished literary figures to idealized women "utilized to stimulate men's amorous fantasies" (83).

By contrast, the fourth chapter, "The Pillow Book for Early Modern Female Readers," examines popular adaptations of the Makura no sōshi aimed at a female readership. These texts have very different concerns from those in the previous chapters, and Ivanova's comparison is instructive. Here the Makura no sōshi and its author represent-and impart - virtues and knowledge crucial for female self-cultivation within Tokugawa society's patriarchal structure. Where the male-oriented adaptations of the Makura no sōshi involved the construction of the pleasure quarters as a world outside the normal social hierarchy, the female-oriented adaptations are intended to bestow upon their readers opportunities for upward social mobility within that hierarchy through self-improvement. In these works, Sei Shōnagon takes on a different role: while still alluring and erudite, she is cast as an experienced older woman offering advice to younger women in need of education. The texts that Ivanova examines offer guidance to their female readers across a range of areas, but the main focal points are literary erudition and skill in navigating intimate male-female relationships, presented in these texts as ideal feminine qualities (albeit situated firmly within the context of women's relationships with men). As with the denizens of the pleasure quarters, the elegance and refinement of court society served as a model of comportment, in these texts, for women preparing for employment or married life.

Chapter 5, "Shaping the Woman Writer," focuses on the figure of Sei Shōnagon herself. As with so many early literary figures, a lack of reliable biographical information on Sei Shōnagon has made her image malleable in the hands of later readers and writers. As Ivanova shows, this process 
began in the medieval period (1185-1603), with the emergence of narratives depicting the miserable old age of Heian-period female authors such as Sei Shōnagon and Ono no Komachi (mid-ninth century). In the Edo period, however, the dominant image of Sei Shōnagon "was that of a talented and intelligent woman" (130), as seen in the texts for women mentioned above, and elsewhere. Nationalistic concerns amongst Meijiperiod scholars led to a more negative view of Sei Shōnagon; in particular, she was made part of "an antagonistic dyad" (139) in which she was characterized as a "boastful literary woman" (143) and negatively compared to Murasaki Shikibu (ca. 973-1014), author of the Genji monogatari. Her reception in other Meiji-period contexts, however, was more positive: in school textbooks and women's magazines of the time, she is praised for her literary talents alongside Murasaki Shikibu, both women symbolizing Japan's cultural heritage. As Ivanova shows, what all these reconstructions of Sei Shōnagon's personality have in common is that they are made on the basis of (selected parts of) the Makura no sōshi, and all serve the interests of their creators in some way.

The final chapter, "New Markets for Japanese Classics," examines the position of the Makura no sōshi in Japan and elsewhere today. Ivanova discusses the place of the Makura no sōshi in the school curriculum, noting that the opening section, "In spring, the dawn," has been part of the middle- and high-school curricula for decades, and in 2008 also became part of the elementary school curriculum. More appealing to contemporary readers, however, are the adaptations of the Makura no sōshi into modern Japanese translations, graphic novels, or television. Once again Sei Shōnagon is constructed in a way that appeals to her audience: here she is a working woman, finding common ground with her readers across the span of a thousand years. The non-Japanese Makura no sōshi adaptation that Ivanova concentrates on in the latter part of the chapter is Peter Greenaway's film The Pillow Book (1996), which was loosely inspired by Arthur Waley's partial translation of the Makura no sōshi (The PillowBook of Sei Shōnagon, 1928). Like Waley's translation, the Greenaway film focuses on the protagonist's intimate relationships, representing the Makura no sōshi as a record of erotic encounters, an approach firmly embedded in hackneyed Western images of "Japan as an exotic country filled with sexually alluring women" (157).

This groundbreaking study is well planned and well executed, not only casting light on the reception history of a familiar classic, but using that history as a lens through which to examine larger issues relating to text, 
author, gender and nation. The idea of the Makura no sōshi as an authoritative catalogue of information and guide to behavior in early modern Japan was a powerful and persistent one, and Ivanova shows us interested parties making use of the cultural capital of the Makura no sōshi while skillfully adapting it for uses suited to their own time and place (a process which is ongoing today). Ivanova's clear and accessible arguments and prose make this book ideal for use with students, and the breadth of her scope makes it useful reading for historians as well as scholars of literature. Apart from its detailed and well-argued dissection of Edo-period representations and reconstructions of the Makura no sōshi and its author, Ivanova's study is also very valuable for its deconstruction of negative images of Sei Shōnagon that persist in discussions of the Makura no sōshi today. By showing the positive ways in which Sei Shōnagon has been represented in early modern contexts, Ivanova succeeds in freeing her from the mold into which twentieth-century scholars have forced her, "unbinding" the author and her text and opening up new possibilities for the study and appreciation of the Makura no sōshi. 